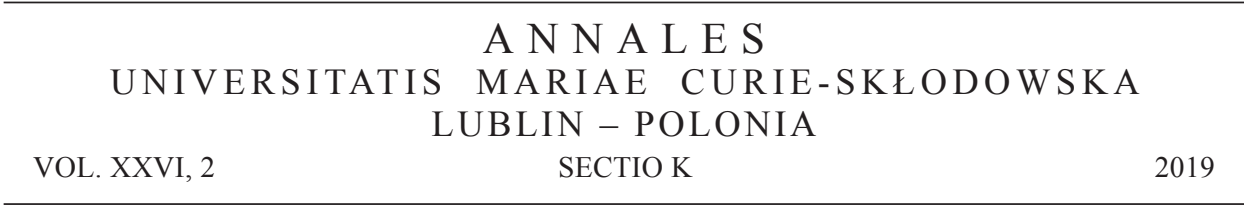

Gdańsk University of Technology, Faculty of Management and Economics

\author{
KRYSTYNA GOMÓŁKA
}

ORCID ID: https://orcid.org/0000-0002-7046-0729

\title{
Ukraine’s Energy Security in Strategies
}

\begin{abstract}
During the independence period, the Ukrainian government has published two energy security strategies. The first strategy was adopted in 2006 and the second one in 2016. Both documents provided a similar definition of energy security. The aims of the first strategy, covering the period 2006-2030, were the restructuring of the fuel and energy complex using new technologies, increase of energy efficiency and ensuring market prices of energy generation and sale. The second strategy was much more extensive and envisaged the implementation of changes in three stages until 2035. The changes proposed in the document are reasonable from the point of view of Ukraine's energy security. The strategy does not take an explicit position on decarbonisation, although it provides for the modernisation of power plants and closure of unprofitable mines. Some of the goals of the Ukrainian energy sector were only roughly outlined and therefore need elaboration and clear indication of how they would be achieved. The aim of this article is to analyse the reforms and measures provided for in Ukraine's strategies designed to ensure the country's energy security. The research hypothesis is as follows: The reforms envisaged in the strategies can effectively contribute to ensuring the state's energy security. To test this hypothesis, the author formulated the following research questions: 1 . How did the two energy strategies define security?; 2 . Which elements of energy policy were considered to be the most important in the first strategy document?; 3 . What energy security components are listed in the second strategy document?; 4. Were the measures specified in the first and second strategies capable of ensuring the energy security of Ukraine? The applied research methods were the following: literature research, comparison method and content analysis.
\end{abstract}

Key words: strategy, energy security, Ukraine, mineral resources

\section{INTRODUCTION}

Ukraine occupies an area of $603,000 \mathrm{~km}^{2}$ and in $2017 \mathrm{had}$ a population of 44.83 million [Ukraine 2018]. The main rivers of Ukraine are the Dnieper, the Don and the Dniester, flowing in the southern direction and discharging into the Azov Sea 
and the Black Sea. The largest river of Ukraine is the Dnieper, on which dams have been built for hydroelectric power stations [Lavrynenko 2011: 69].

Ukraine has abundant deposits of iron ore, coal (including anthracite) and manganese ores. They are located close to the heavy industry and mining centres. Ukraine does not have sufficient natural gas or crude oil resources and therefore imports them from Russia. Since the early 1990s, the country has been among the top energy consumers in the region in terms of energy efficiency. In 2012, the share of organic fuels in electrical energy production was $45.8 \%$ and the share of nuclear energy $-44.2 \%$. Centralised supply of heat is very common in Ukraine. More than $40 \%$ of households are connected to the district heating systems and $50 \%$ of the heat produced in this way is received by the industry. The most commonly used fuels in combined heat and power (CHP) plants include natural gas, hydrocarbons and carbon. Other fuels are far less used for energy production in Ukraine [Kłaczyński 2010: 84].

The aim of this article is to analyse the reforms and measures provided for in Ukraine's strategies designed to ensure the country's energy security. The research hypothesis is as follows: The reforms envisaged in the strategies can effectively contribute to ensuring the state's energy security. To test this hypothesis, the author formulated the following research questions: 1 . How did the two energy strategies define security?; 2 . Which elements of energy policy were considered to be the most important in the first strategy document?; 3 . What energy security components are listed in the second strategy document?; 4 . Were the measures specified in the first and second strategies capable of ensuring the energy security of Ukraine? The applied research methods were the following: literature research, comparison method and content analysis. The article is based on the texts of Ukrainian energy security strategies and relevant literature.

\section{ENERGY SECURITY OF UKRAINE IN STRATEGY I}

Since 1992, the government of independent Ukraine has adopted a series of documents defining the principles of the national energy policy. These included: the State Programme for Energy Saving [Prohrama enerhozberezhennya dlya naselennya 2015], the Public Aid Programme for the Development of Alternative and Renewable Energy Sources [Rozvytok vidnovlyuvanykh dzherel enerhiyi v Ukrayini 2017], the National Programme for "Oil and Gas in Ukraine until 2010" [Pro Natsional'nu prohramu "Nafta i haz Ukrainy do 2010 roku"] and the National Energy Programme of Ukraine until 2010 [Pro Natsional'nu enerhetychnu prohramu Ukrainy do 2010 roku]. On 15 March 2006, the first Energy Strategy of Ukraine until 2030 prepared by the Ministry of Fuel and Energy of Ukraine and a group of experts from the Ukrainian National Academy of Sciences was approved [Energeticheskaya strategiya Ukrainy na period do 2030 goda]. The strategy had been developed in line with the concept of fuel and energy complex development for 2006-2030. The main condition had not 
been met, however, since the development of strategies should have been preceded by the approval of the document titled "Basic Directions of the Economic Strategy of Ukraine until 2030" which had not existed before the adoption of the strategy [Enerhetychna stratehiya Ukrayiny: priorytetni napryamy zberezhennya enerhoresursiv].

The publication of the strategy in 2006 was connected with the signing of the protocol in 2005 between the EU and Ukraine concerning cooperation in the field of energy [Kajdarowicz 2015: 155]. The document provided for multi-level cooperation between the partners in the form of annual work plans covering the following issues: 1) nuclear safety; 2) integration of the gas and electricity markets; 3 ) reliability of supply and transit of hydrocarbons; 4) reducing the importance of the coal sector; 5) increased energy efficiency.

The main objectives of the first energy strategy were: restructuring of the fuel and energy complex with the use of new technology, increased productivity and ensuring market conditions for the production and sale of energy. The goals of the strategy also included an increased use of natural resources and the development of the technical capacity of the fuel and energy complex in the framework of effective economic development [Energeticheskaya strategiya Ukrainy na period do 2030 goda].

The strategy document defined the concept of energy security as the state's ability to ensure an effective utilisation of the fuel and energy resources, diversification of sources and routes of supply of raw materials and energy carriers in the period of peace or war and adaptation of the Ukrainian energy industry to the changing situation in Europe. The strategy covered a range of measures in the area of power engineering, nuclear energy, fuels - coal, oil and natural gas energy efficiency and certain aspects of environmental protection.

In strategic terms, it was of fundamental importance to strengthen the position of Ukraine in the European energy system as a transit country for the transfer of oil and gas from Russia and Central Asia to EU countries. In this context, Ukraine's cooperation with partners, particularly Poland, in the implementation of the oil transport corridor Odessa - Brody - Gdańsk was considered critical. For the future, it was planned to expand the transport of that fuel from the Caspian Sea region and from the Middle East. It was also deemed necessary to raise the energy system standards in Ukraine and gradually approximate the European requirements.

The strategy emphasised that the geographic location of Ukraine enables it to play an important role on the European energy market. The capacity of transmission lines was also considered vital for the state, as a source of budget revenues in foreign currencies. The size of oil and gas transit played an important role in the analysis of the energy security of Ukraine and Europe, because, according to the International Energy Agency, $80 \%$ of natural gas and $17 \%$ of oil transferred to European countries passed across the Ukrainian territory [Gromadzki, Konończuk 2007]. The Ukrainian power industry was heavily dependent on the imports of raw materials. $75-80 \%$ of imported gas and $85-90 \%$ of oil consumed by the Ukrainian population came from Russia. Standards of energy security required that the imports of fuels from each 
source did not exceed $25-30 \%$ of total supplied, which necessitated cooperation with three or four suppliers. Ukrainian deposits of oil, natural gas, coal and shale gas were utilised to a limited extent. In 2005, the production of electricity in Ukraine accounted for $10-12 \%$ of oil, $20-25 \%$ of natural gas and $90-92 \%$ of coal consumed in that year. The renewable energy sources were used only in 3\%, a substantial proportion of which was provided by hydroelectric power stations. In 2001-2005, the amount of funding for the so-called energy efficient projects was just 7 million hryvnia - far lower than the planned 25 million. The privatisation of oil processing plants at the turn of the $21^{\text {st }}$ century was a contributing factor to a decrease in the oil processing capacity and the volume of petroleum products. However, thanks to foreign companies, a slight increase of oil extraction was noted.

The energy security strategy stressed the need to improve the energy security of Ukraine by:

1) increasing extraction efficiency and power consumption savings (geological survey, modernisation of fixed assets of enterprises, upgrading of the fuel and energy complex and introduction of energy efficient technologies in production and construction industry);

2) optimising the structure of the country's energy balance (increasing the share of own fuels in the production of energy, acquiring shares in enterprises producing fuels in foreign countries, development of renewable energy sources);

3) diversification of external sources of energy supplies, seeking new suppliers in Azerbaijan, Kazakhstan, Turkmenistan, Uzbekistan, Iran, Algeria, Egypt and the Persian Gulf states [Rybak, Solarz 2014: 75-76];

4) strengthening the position of Ukraine in the international energy carrier transport system (participation of Ukraine in new transmission line construction projects, increasing the capacity of Ukrainian transmission lines, improving the mechanism of energy cooperation between Ukraine, Russia and the European Union).

Focusing on energy security, the 2006 strategy did not contain any plans for the development of thermal energy market in Ukraine. It merely noted that in 1993, more than $70 \%$ of demand for this form of energy was covered by cogeneration (CHP) plants and coal-fired district heating plants. In 2005, they produced only ca. $52-54 \%$ of thermal energy and it was suggested that the share of thermal energy from these source should be further reduced after 2015. Future heat supply plans were to be developed for a period of 10-15 years and synchronised with the cities' local development plans. Such programs were prepared for some cities of Ukraine [Kakaya model'rynka teplovoy energii nuzhna Ukraine 2017]. The tasks assigned to the state government included seeking new energy solutions and attracting foreign investors to the energy sector. The authors of the document failed to consider regional energy issues, including the determination of locations and capacities of new power plants. They merely noted that the economic operators in the energy market should operate in economically viable conditions. The strategy devoted little attention to environmental protection [Balyuk 2011: 85-94]. 


\section{MAIN POINTS OF THE SECOND ENERGY SECURITY STRATEGY}

The new "Energy Strategy of Ukraine until 2035 - security, energy efficiency, competitiveness" was presented in December 2016 [Enerhetychna stratehiya Ukrayiny do 2035 roku... 2017]. The document had been prepared in line with the "Sustainable Development Strategy Ukraine 2020", approved by Decree of the President of Ukraine No. 5 of 12 January 2015 providing for the energy sector reform and implementation of an energy efficiency programme [Pro Stratehiyu staloho rozvytku "Ukraina-2020"]. The intended change in the approach to the government's energy policy was highlighted in the preamble. It was proposed to depart from the sector model dominated by large producers of fossil fuels, inefficient transmission networks and imperfect competition of gas, electricity and coal markets, and to adopt a new solution that would eliminate the dominance of a single fuel type and the same supply routes, instead favouring increased energy efficiency and the use of renewable energy sources. The strategy also provided for the implementation of solutions against climate change and adaptation of the energy sector to global standards. That task posed new economic and technological challenges to Ukraine, including the implementation of innovative solutions in the area of mining and processing of fossil fuels, supplies, consumption and the development of a new energy policy.

The document emphasised the difficult circumstances in which it had been developed, following the annexation of a part of the Ukrainian territory by Russia [Ćwiek-Karpowicz 2016: 139]. It was suggested that the Ukrainian energy complex must undergo transformation to factor in the foreign military aggression. The strategy implied reduction of the energy intensity of the national economy, diversification of sources and supply routes of energy, increasing the domestic production of fuels and reducing their imports. The energy intensity of the economy was to be reduced by $100 \%$ in $2017-2020$ and by $200 \%$ until 2035 , compared to 1992 . Achievement of that goal required advanced technological solutions, investment, legislative and structural changes, as well as alignment of the Ukrainian energy law with the European laws. It is assumed that the share of direct investment from the state budget in energy infrastructure should not exceed $5.1 \%$ of the value of investment [Enerhetychna stratehiya Ukrayiny do 2035 roku... 2017].

In 2015 , Ukraine imported $51.6 \%$ of the fuels consumed which, according to the strategy, compromised its energy security. The goal defined in the document was to achieve reliable and environmentally-friendly supply of fuel and energy for the needs of the economy. The vision outlined in the strategy was as follows: Ukraine's energy sector as a guarantee of economic sovereignty of the state and the basis for sustainable development of a competitive economy forming part of an integral European energy sphere.

One of the strategy priorities was the concept of "energy efficient society" to be realised through: 1) improving energy management in accordance with international standards and agreements; 2) stimulating energy savings by consumers and raising the 
citizens' awareness of the need for energy efficiency; 3) promoting energy efficiency; 4) reducing energy losses in transmission and distribution; 5) ensuring transparent accounting rules in the energy sector; 6) regular monitoring of the energy balance of Ukraine; 7) reduction of the energy intensity of industry by half before 2035; 8) creating new resource bases, introduction of recycling, creating stocks and reserves, diversification of sources and supply routes (not more than $30 \%$ energy resources from one source), minimising imports, undertaking the production of hydrocarbons in Ukraine, rapid development of alternative energy sources; 9) optimisation of the energy balance; 10) creation of a crisis management system in the sector based on NATO and EU best practices; 11) application of best solutions in the field of environmental protection; 12) modernisation and ensuring reliable operation of energy infrastructure; 13) integration of Ukraine's energy system with the European system. The next task set for Ukraine was decarbonisation and combating climate change, including the reduction of emissions of particulate matter to the atmosphere [Federova 2012]. An important role in the implementation of that task was to be played by nuclear energy, hydroelectric power and wind energy, as emitting less greenhouse gases. ${ }^{1}$ The government of Ukraine identified nuclear power as the most economical mode of energy production and suggested that new nuclear plants should be built. For the next decade of the $21^{\text {st }}$ century, the government envisaged the replacement of combustion engines in cars and machines with electrical motors or hydrogen engines.

The main aim of the strategy was to ensure Ukraine's energy autonomy [Czech 2015: 25-26]. According to the data of the Ukrainian State Statistical Services for 2015 , the energy production structure was as follows: $28.9 \%$ - natural gas, $25.5 \%$ - nuclear energy, $30 \%$ - coal, $11.6 \%$ - oil and petroleum products, $2.2 \%$ - biomass, $1.1 \%$ - geothermal energy, $0.6 \%$ - hydropower, $0.1 \%$ - solar energy. The combined share of alternative energy sources was $4 \%$. To achieve energy independence it was necessary to: 1) create competitive markets for electricity, thermal energy, coal, oil, gas and petroleum products, and for their transport, with the assumption of an unstable pricing policy; 2) promote local energy initiatives, i.e. electricity and heat generation with utilisation of the regional resources, simplification of transit procedures, introduction of best practices in the management of oil and gas resources, adjustment of legislation and upgrading of technical infrastructure [Chevhanova, Khadartsev 2017: 67-75].

To achieve the objectives outlined in the strategy, it was deemed imperative to create technological parks generating innovative solutions for the energy sector, create the opportunities for European companies to purchase of natural gas on the

1 Particulates emissions per GDP in Ukraine is very high, reaching $0.9 \mathrm{~kg}$ per 1 dollar of GDP, as compared to $0.2 \mathrm{~kg}$ in Germany, France, Great Britain, Spain and Italy. The high energy intensity and $\mathrm{CO}_{2}$ emissions per unit of GDP is due to the structure of the industry that consumes $43 \%$ of energy. Ukraine was present at the climate conference in Paris between 30 November and 15 December 2015, Historyczne porozumienie w sprawie klimatu zostało zawarte, http://www.unic.un.org.pl/szczyt-klimatyczny-w-paryzu-2015/ historyczne-porozumienie-w-sprawie-klimatu-zosta\%C5\%82o-zawarte (access: 16.03.2018). 
eastern border of Ukraine, and to equip the facilities on that border with gas quality measurement stations. Taking into account the importance of Ukraine as a transit country in the supply of oil to the EU, it was also considered necessary to tighten the cooperation in the use of transport infrastructure, to diversify the sources and supply routes of oil to European countries and to create and maintain the required stock levels of crude oil and petroleum products in Ukraine.

The text of the strategy, drawn up by state institutions with the support of European experts, identified the strategic objectives of the Ukrainian energy sector until 2035. Their implementation was divided into three main stages. In the first phase, entitled "Reform of the energy sector until 2020", the main emphasis was on implementing the reforms and creating a competitive environment conducive to investment. The modernisation of electricity generation efforts was focused on: introducing a new electrical power market model on the basis of the Act on the Ukrainian electricity market, separating the functions of distribution systems operator from the supply, development of tariffs based on economic criteria, implementing programmes to improve the utilisation of production capacity in state-owned enterprises, exporting electricity to and importing it from the European Union countries on a commercial basis, increasing the capacity of power grids, construction of new energy facilities, adoption of a plan to decommission old nuclear power plants after 2030, selection of reactor technologies for new nuclear power plants and approval of the long-term Programme for the Development of Nuclear Energy in Ukraine, ending the privatisation of mines, establishment of technical requirements concerning energy supply in accordance with the commitments made in the European Union Association Agreement, and setting the minimum standards of energy security [Mikhaylov 2017].

One of the facts stressed in the strategy was that the level of the emission in Ukraine in 2015 exceeded the EU standards 7-80 times on average, depending on the type of pollutant. Plans were made to reduce the emission of $\mathrm{SO}_{2}$ by 2028 and NOx by 2033. To achieve that goal, it was necessary to restructure the coal industry (inter alia, by liquidation of unprofitable coal mines) and rehabilitate the land after discontinuing the mine operation. It was provided that after 2020, Ukraine would be able to meet the requirements concerning the greenhouse gas emissions by means of emissions trading [Dyduch 2013: 85-86]. Therefore, the main objective in the area of environmental protection was a radical cut in greenhouse gas emission to be achieved by financing the construction of disposal facilities for the waste generated by the energy and fuel complex, envisaged in the framework of a national pollution reduction plan [Natsional'nyy plan skorochennya vykydiv ne vidpovidaye mizhnarodnym zobovyazannyam ta interesam Ukrayiny - NETSU]. The strategy called for an amendment of the energy law to enable better coordination of the collection and treatment of waste from power plants and construction of radioactive waste storage facilities. It included upgrading of old-type power plants, implementation of an 
environmental management system, and development of a national nuclear power plant decommissioning programme.

The main directions for the energy efficiency improvement of the Ukrainian economy were identified as: education of citizens on energy saving, incentives for households that use highly energy-efficient lighting and heating systems, modernisation of transmission and distribution systems, energy labelling of household appliances, providing the instrumentation for measuring the energy use in buildings, reducing heat losses of buildings (thermal insulation of walls, roofs and cellars, replacement of windows and doors) and increasing the use of alternative energy sources to $12 \%$.

A short-term solution for Ukraine's energy security consisted of negotiations with Russia and the European Union on fuel transit, whereas a long-term one involved diversification of supply and reducing the dependence on a particular supplier or route. In the gas sector, the main objective of the strategy was considered optimisation of the consumption balance, increasing the production of natural gas and improvement of distribution networks and storage facilities. The document provided that the consumption of natural gas in 2020 should be approximately at the level of countries of Central and Eastern Europe. It was also recommended to reduce the imports of gas, develop Ukraine's own resource base by increasing the production of hydrocarbons, and conduct geophysical survey in the waters of the Black Sea and the Azov Sea and in the area adjacent to the Crimea once that territory was recovered by Ukraine. In the natural gas sector, the most important undertakings were identified as: setting the market prices of gas for all consumer categories, alignment of legislation in the field of fuel transfer and storage with the requirements of the European Union, and ensuring competition in the segment of wholesale and retail supply for domestic customers. In order to increase the security of supply it was considered necessary to expand the underground gas storage facilities [Belica 2014: 67-86].

The goals set for the oil sector included reducing the use of traditional fuel by road transport, promotion of environmentally-friendly fuels, modernisation of machinery and equipment, satisfying 50\% of demand for low-emission Euro-5 petroleum products in the domestic market, improving the state fuel quality monitoring system, publishing information on the companies that distribute low quality fuels. The factors expected to promote diversification of supply of oil were the use of alternative materials, reduction of port charges, increasing the security of oil transport, increasing oil supplies from countries other than Russia and ensuring minimum stocks of oil and petroleum products for a period of 90 days.

With respect to the coal sector, the strategy recommended state management of the export and import of coal products, restructuring of hard coal mining and introduction of a commodity exchange for coal products. The objective for the nuclear fuel sector was to ensure growth of the domestic extraction of uranium, to examine the possibility of undertaking the production of and stocking nuclear 
fuel in Ukraine and to develop a plan for the disposal of spent fuel [Romanenko, Kuz'menko, Afanas'yev 2012].

The second stage of implementation of the energy strategy "Optimisation and innovative development of energy infrastructure" was to begin in 2025. The plan for that period included full integration of the Ukrainian energy network with the European transmission system, further tightening of cooperation with the Central European countries in energy supply, implementation of investment projects under the national emissions reduction plan, creating local heating supply systems on the basis of cost-effectiveness criteria, taking account of the local fuel sources and improving the performance of district heating systems. The plan provided for the construction of new power infrastructure, utilisation of resources of the Ukrainian raw material market, modernisation of the accounting systems and increasing the consumers' impact on the management of energy demand. The second phase was to involve reduction of the electricity generated from fossil fuels in favour of nuclear energy. That is why it was considered necessary to extend the period of operation of selected nuclear power plants and to build new ones in accordance with the Programme for the Development of Nuclear Energy in Ukraine [Trusewicz 2016: 16]. The increased energy efficiency targets were to be met by tightening the construction standards for buildings, providing loans for economic operators for technological upgrade in the power industry and implementation of demonstration and pilot projects, and introduction of efficiency standards in transport.

The plans for the oil sector included intensification of prospecting for and extraction of oil and gas for domestic consumers, optimisation of supply diversification and routes, increasing the production of second-generation biofuels and electricity in transport, and achieving a $20 \%$ share of renewable sources in energy consumption for heating of facilities. In the gas sector, the domestic demand was to be met in full by natural gas produced in Ukraine. At this stage the "smart" grids project was planned to be launched.

In the third stage, titled "Ensuring sustainable development" and scheduled to be implemented by 2035, development of a next generation energy sector was envisaged, to be achieved by the use of new solutions in the construction of power plants and new energy storage technologies. The goal of increasing energy efficiency and improving environmental protection parameters was intended to be achieved through the construction of passive houses, cutting $\mathrm{SO}_{2}$ and $\mathrm{NOx}$ emissions in accordance with the national emission reduction plan and by greenhouse gas emissions trading [Kuznyetsova 2010: 243].

The gas sector was supposed to achieve an increase in the domestic production of that fuel derived from non-conventional sources. The oil sector was to complete the project of "digitisation" of oil fields and Internet platform visualisation to track changes in the field. In respect of the sale of petroleum products, the strategy recommended stimulating the development of a network of electric refuelling stations. As to the oil sector, the need to maximise production in the existing mines to meet 
Ukraine's domestic needs was emphasised. The strategy also provided for better utilisation of renewable energy sources: hydropower and biofuels, as well as household waste. It was assumed the alternative sources should meet $21.9 \%$ of demand for thermal energy.

The implementation of the strategy was conditional upon the improvement of business operating conditions in Ukraine, introduction of independent energy market surveillance, introduction of market prices for energy and fuels and thus the establishment of an energy market, implementation of the Act on the electricity market and integration of the Ukrainian and EU power infrastructures. The introduction of public-private partnership mechanisms was seen as a means of increasing the investment attraction of the energy sector. The strategy also named the specific ministries to be in charge of its implementation. The tasks assigned to the Cabinet of Ministers and the National Security and Defence Council of Ukraine included: approving the action plans and socio-economic development programmes at the national, regional and local level, granting loans to economic operators and preparing five-year forecasts of fuel consumption in Ukraine. The individual ministries were also given a share of responsibility for implementing the strategy. The Ministry of Energy and Coal Industry was responsible for monitoring the implementation of the strategy, developing an action plan for the development of nuclear power plants, preparing a report on the implementation of the state's energy policy, monitoring the compliance of the energy sector entities and publication of progress reports on the implementation of the successive stages of the strategy. The Ministry of Economic Development and Trade participated in the preparation of the programmes concerning the implementation of public-private partnership and stimulated economic restructuring, inter alia, in the energy sector. The Ministry for Regional Development, Building and Housing was responsible for the preparation of legislation to enable the implementation of the state policy in respect of the supply of heating for companies and private consumers, approved the regional heating modernisation programs and local district heating development plans, and supported initiatives relating to the energy efficiency of buildings. The Ministry of Foreign Affairs participated in the efforts of international organisations in the field of energy and ecology, protected the interests of the energy sector in cross-border projects, and consulted on the diversification of energy supply routes. The Ministry of Ecology and Natural Resources participated in the initiatives relating to climate change and environmental protection and monitored fulfilment of the obligations assumed at the 2015 United Nations Climate Change Conference [Semerak 2018], and the implementation of international environmental protection agreements in accordance with the Aarhus Convention of 1998. Local authorities were obliged to ensure the implementation of the strategy by preparing plans for regional programmes of district heating modernisation, coordination of investment plans of municipal energy companies and implementation of energy efficiency programmes [Borko 2013:57]. 


\section{CONCLUSIONS}

Two energy security strategies have been published since Ukraine became an independent state. The first was adopted by the government in 2006, and the other ten years later, in 2016. Both documents were based on a similar definition of energy security, understood as the state's ability to ensure an effective use of the fuel and energy resource base and diversification of fuel sources and routes of supply, and to create favourable conditions for the adaptation of new technology solutions and fuel prices. The goal of the first strategy, covering the period from 2006 to 2030 , was to restructure the fuel and energy complex with the use of new technologies, to increase the extraction of fuels and the efficiency of energy generation and to ensure market prices of energy production and sale. Nevertheless, the strategy failed to identify uniform mechanisms of energy market development and to address the issue of decommissioning of the old power plants and building new ones or propose effective technology solutions in the energy sector. Long-term plans for the heating supply in Ukraine were linked with the local land use plans of individual cities, but not all municipalities have prepared such plans. The first strategy did not pay much attention to environmental protection.

The second energy security strategy covered the period until 2035, and envisaged three stages of implementation of its objectives: 1) modernisation and reform; 2) market integration and strengthening; 3 ) innovation. The strategy stipulated that the energy intensity of the Ukrainian economy should be halved by 2035. It was assumed that Ukraine would produce excess electricity before 2025, but later an energy deficit would be observed due to the decommissioning of some power plants. In that period, a new contract with Russia would be signed on the transit of gas to EU countries and the sale of fuel would be transferred from the western to the eastern border of Ukraine. The strategy did not take an explicit position on decarbonisation, although it provided for the modernisation of power plants and closure of unprofitable mines. The nuclear sector was also to undergo certain changes. The strategy suggested intensification of uranium extraction and expansion of the storage facilities for spent fuel. A new goal was established to increase the share of renewable sources in the energy mix to $21.9 \%$ by 2035 .

Not all the changes proposed in the document were possible to implement within the suggested time frame. Many issues referred to in the first strategy were repeated in the second document, which means that the degree of strategy implementation was not high. Both documents lacked flexibility in terms of different scenarios, and the indicated milestones were arbitrary. Some of the issues of the Ukrainian energy sector were only briefly addressed and therefore need more elaborate solution which could effectively guarantee the energy security of the state. 


\section{BIBLIOGRAPHY}

Balyuk, H. 2011. Problemy zakonodavchoyi rehlamentatsiyi ta realizatsiyi v Ukrayini ekolohichnoyi skladovoyi kontseptsiyi staloho rozvytku, "Pravo Ukrayiny", №. 2 [Балюк, Г. 2011. Проблеми законодавчої регламентації та реалізації в Україні екологічної складової концепції сталого розвитку, «Право України», № 2].

Belica, B. 2014. Dywersyfikacja kierunków dostaw gazu ziemnego na Ukrainę - cel polityczny czy instrument negocjacyjny, [in:] Bezpieczeństwo energetyczne. Rynki surowców i energii. Teraźniejszość i przyszłość, t. 1: Polityka-gospodarka-zasoby naturalne i logistyka, P. Kwiatkiewicz (ed.), Fundacja na Rzecz Czystej Energii, Poznań.

Borko, H. 2014. Koncepcje i instrumenty zarządzania strategicznego bezpieczeństwem energetycznym: przyktad Ukrainy, [in:] Rozwój regionalny i lokalny w Europie Środkowo-Wschodniej w warunkach kryzysu i reformy, M. Czupich, A. Ignasiak-Szulc, M. Kola-Bezka (eds.), Wydawnictwo Naukowe Uniwersytetu Mikołaja Kopernika, Torun.

Chevhanova, V., Khadartsev, O. 2017. Increase of Energy Efficiency of the Ukrainian Economy: Problems and Priorities, "Scientific Journal of Polonia University", vol. 21(2), pp. 67-75, DOI: https://doi. org/10.23856/2107.

Czech, A. 2015. Wspótpraca Unii Europejskiej w zakresie bezpieczeństwa energetycznego z wybranymi państwami, "Studia Ekonomiczne. Zeszyty Naukowe Uniwersytetu Ekonomicznego w Katowicach", vol. 228, pp. 22-36.

Ćwiek-Karpowicz, J. 2016. Postrzeganie i definiowanie bezpieczeństwa energetycznego $w$ warunkach kryzysu na Ukrainie, "Polityka Energetyczna", vol. 19(1), pp. 137-148.

Dyduch, J. 2013. Handel uprawnieniami do emisji zanieczyszczeń powietrza, Polskie Wydawnictwo Ekonomiczne, Warszawa.

Energeticheskaya strategiya Ukrainy na period do 2030 goda: problemnyye voprosy soderzhaniya i realizatsii [Энергетическая стратегия Украины на период до 2030 года: проблемные вопросы содержания и реализаиии], https://zn.ua/ECONOMICS/energeticheskaya_strategiya_ukrainy_na_period_do_2030_goda_problemnye_voprosy_soderzhaniya_i_realiza.html (access: 2.09.2018).

Enerhetychna stratehiya Ukrayiny do 2035 roku - bezpeka, enerhoefektyvnist', konkurentospromozhnist'. 2017 [Енергетична стратегія Украӥни до 2035 року - безпека, енергоефективність, конкурентоспроможність ], http://mpe.kmu.gov.ua/minugol/control/publish/article?art $\mathrm{id}=245234085$ (access: 5.09.2018).

Enerhetychna stratehiya Ukrayiny: priorytetni napryamy zberezhennya enerhoresursiv [Енергетична стратегія України: пріоритетні напрями збереження енергоресурсів], http://mpe.kmu.gov.ua/ minugol/control/publish/article?art_id=93853 (access: 3.08.2018).

Federova, W.A. 2012. Perspektywy wzmocnienia bezpieczeństwa energetycznego Ukrainy, http://www. rynekwschodni.pl/news/Perspektywy-wzmocnienia-bezpieczenstwa-energetycznego-Ukrainy, 752 (access: 10.09.2018).

Gromadzki, G., Konończuk, W. 2007. Energetyczna gra: Ukraina, Mołdawia i Białoruś między Unia a Rosja, Fundacja im. Stefana Batorego, Warszawa.

Historyczne porozumienie $w$ sprawie klimatu zostało zawarte. 2018, http://www.unic.un.org.pl/szczytklimatyczny-w-paryzu-2015/historyczne-porozumienie-w-sprawie-klimatu-zosta\%C5\%82o-zawarte (access: 16.03.2018).

Kajdarowicz, Ch. 2015. Energy Security of Ukraine, "Zeszyty Naukowe. Podkarpacka Szkoła Wyższa im. bł. ks. Władysława Findysza w Jaśle", no. 12.

Kakaya model' rynka teplovoy energii nuzhna Ukraine. 2017 [Какая модель рынка тепловой энергии нужна Украине. 2017], https://zn.ua/energy_market/kakaya-model-rynka-teplovoy-energii-nuzhnaukraine-_html (access: 5.10.2018).

Kłaczyński, R. 2010. Sektor energetyczny: stan obecny i perspektywy, "Nowa Ukraina: Zeszyty HistorycznoPolitologiczne", vol. 9/10. 
Kuznyetsova, S.V. 2010. Teoretychni ta praktychni aspekty vykonannya v Ukrayini Kiots'koho protokolu do Ramkovoyi konventsiyi Orhanizatsiyi Ob'yednanykh Natsiy pro zminu klimatu, "Chasopys Kyyivs'koho uniwersytetu prava", vol. 2 [Кузнєцова, С.В. 2010. Теоретичні та практичні аспекти виконання в Україні Кіотського протоколу до Рамкової конвениї̈ Організаиії Об'є 'наних Націй про зміну клімату, «Часопис Київського університету права», № 2].

Lavrynenko, G. 2011. Polityka energetyczna Ukrainy - ustawodawstwo, praktyka, kierunki rozwoju, "Społeczeństwo i Polityka", vol. 2(27).

Mikhaylov, A. 2017. Novaya model' rynka teplovoy energii privlekayet trilliony investitsiy [Михайлов, А. 2017. Новая модель рынка тепловой энергии привлечет триллионы инвестиций], http://www. rosbalt.ru/business/2017/02/08/1590010.html (access: 16.11.2018).

Natsional'nyy plan skorochennya vykydiv ne vidpovidaye mizhnarodnym zobovyazannyam ta interesam Ukrayiny - NETSU [Національний план скорочення викидів не відповідає міжнародним зобов'язанням та інтересам Украӥни - НЕЦУ], http://necu.org.ua/natsionalnyy-plan-skorochennya-vykydiv-ne-vidpovidaye-mizhnarodnym-zobovyazannyam-ta-interesam-ukrayiny (access: 10.03.2018).

Ob Energeticheskoy strategii Ukrainy na period do 2030 goda. 2006 [Об Энергетической стратегии Украины на период до 2030 года. 2006] http://www.esco.co.ua/journal/2006_9/art_181.htm (access: 4.03.2018).

Prohrama enerhozberezhennya dlya naselennya. 2015 [Програма енергозбереження для населення. 2015], http://cg.gov.ua/web_docs/1/2015/10/docs/PROGRAMA_stimulyuvannya_do_zaprovadzhennya_energoefektivnih_zahodiv_naselennya.pdf (access: 1.03.2018).

Pro Natsional'nu enerhetychnu programu Ukrainy do 2010 roku, Verkhovna Rada Ukrainy. Postanova vid 15.05.1996, №. 191/96-ВР [Про Начіональну енергетичну програму України до 2010 року, Верховна Рада України. Постанова від 15.05.1996, № 191/96-BP], https://ips.ligazakon.net/document/view/F960191 (access: 19.11.2018).

Pro Natsional'nu prohramu "Nafta i haz Ukrainy do 2010 roku”, Kabinet Ministriv Ukrayiny. Postanova vid 17.02.1995, №. 125 [Про Національну програму «Нафта і газУкраїнидо 2010 року», Кабінет Міністрів України. Постанова від 17.02.1995, № 125], https://zakon.rada.gov.ua/laws/show/12595-\%D0\%BF (access: 12.10.2018).

Pro Stratehiyu staloho rozvytku “Ukraina - 2020”, Ukaz Prezydenta Ukrayiny. Stratehiya vid 12.01.2015, No. 5/2015 [Про Стратегію сталого розвитку “Україна - 2020”, Указ Президента України. Стратегія від 12.01.2015, № 5/2015].

Romanenko, V.D., Kuz'menko, M.I., Afanas'yev, S.O. 2012. Hidroekolohichna bezpieka atomnoyi enerhetyky v Ukrayini [Романенко, В.Д., Кузьменко, М.І., Афанасьєв, С.О. 2012. Гідроекологічна безпека атомної енергетики в Україні], http://nbuv.gov.ua/j-pdf/vnanu_2012_6_7.pdf (access: 11.09.2018).

Rozvytok vidnovlyuvanykh dzherel enerhiyi v Ukrayini. 2017 [Розвиток відновлюваних джерел енергіï в Україні. 2017], http://energymagazine.com.ua/wp-content/uploads/2017/03/Rozvitok-VDE-v-Ukraini.pdf (access: 01.08.2018).

Rybak, A., Solarz, J. 2014. Ukraińskie próby dywersyfikacji źródet energii i dostaw surowców energetycznych, "Teka Komisji Politologii i Stosunków Międzynarodowych", vol. 9, pp. 75-88, DOI: http:// dx.doi.org/10.17951/teka.2014.0.9.75.

Semerak, O. 2018. Ukrayina hotova pidtrymaty Pol'shchu u pidhotovtsi do Konferentsiyi OON z pytan' klimatu 2018 rokи [Семерак, О. 2018. Украӥна готова підтримати Польщу у підготовиі до Конферениії ООН з питань клімату 2018 року], https://www.kmu.gov.ua/ua/news/250430823 (access: 13.03.2018).

Trusewicz, I. 2016. Strategia energetyczna Ukrainy to atom i woda, "Rzeczpospolita", 22.10, https://energia. rp.pl/energetyka-zawodowa/elektroenergetyka/3011-strategia-energetyczna-ukrainy-to-atom-i-woda (access: 16.03.2018).

Ukraine. 2018, https://www.cia.gov/library/publications/resources/the-world-factbook/geos/up.html (access: 1.03 .2018$)$. 


\section{BIOGRAPHY}

Krystyna Gomólka, full professor of Social Sciences. Her scientific interests comprise problems of political and economic transformation of the post-Soviet countries, relations of the post-Soviet states with the European Union, Poland's eastern foreign policy, cross-border cooperation. Author of twelve books, among them: Transgranichnoye sotrudnichestvo Pol'shi s Respublikoy Ukrainy, Respublikoy Belarusi i Kaliningradskoy oblast'yu Rossiyskoy Federatsii (Kaliningrad 2012) [Трансграничное сотрудничество Польши с Республикой Украины, Республикой Беларуси и Калининградской областью Российской Федерации (Калининград 2012)]; Politika Pol'shi po otnosheniyu k stranam Yuzhnogo Kavkaza na rubezhe XX i XXI vekov (Kaliningrad 2014) [Политика Польши по отношению к странам Южного Кавказа на рубеже ХХ и ХХІ веков (Калининград 2014)]; Stosunki Polski z Armenia, Azerbejdżanem i Gruzja na przełomie XX i XXI w. (Toruń 2015); Polityka Polski wobec studentów, doktorantów i stażystów z państw poradzieckich (Torun 2016); Emigranty iz stran byvshego SSSR v Pol'she (Kaliningrad 2017) [Эмигранты из стран бывшего СССР в Польше (Калининград 2017)]. Author of 170 scientific articles in magazines published in Russia, Belarus, Lithuania, Latvia, Ukraine, Georgia, the Czech Republic, Slovakia and Poland. E-mail: krystyngom@wp.p1 